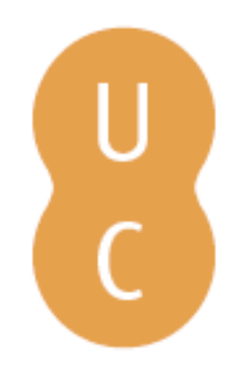

\title{
nombalina
}

O sentido universal do humano em Teixeira de Pascoaes
Autor(es): $\quad$ Soares, Maria Luísa de Castro
Publicado por: Imprensa da Universidade de Coimbra
URL
persistente: URI:http://hdl.handle.net/10316.2/42999
DOI: $\quad$ DOI:https://doi.org/10.14195/978-989-26-1293-5_24

Accessed : $\quad$ 26-Apr-2023 10:25:14

A navegação consulta e descarregamento dos títulos inseridos nas Bibliotecas Digitais UC Digitalis, UC Pombalina e UC Impactum, pressupõem a aceitação plena e sem reservas dos Termos e Condições de Uso destas Bibliotecas Digitais, disponíveis em https://digitalis.uc.pt/pt-pt/termos.

Conforme exposto nos referidos Termos e Condições de Uso, o descarregamento de títulos de acesso restrito requer uma licença válida de autorização devendo o utilizador aceder ao(s) documento(s) a partir de um endereço de IP da instituição detentora da supramencionada licença.

Ao utilizador é apenas permitido o descarregamento para uso pessoal, pelo que o emprego do(s) título(s) descarregado(s) para outro fim, designadamente comercial, carece de autorização do respetivo autor ou editor da obra.

Na medida em que todas as obras da UC Digitalis se encontram protegidas pelo Código do Direito de Autor e Direitos Conexos e demais legislação aplicável, toda a cópia, parcial ou total, deste documento, nos casos em que é legalmente admitida, deverá conter ou fazer-se acompanhar por este aviso.

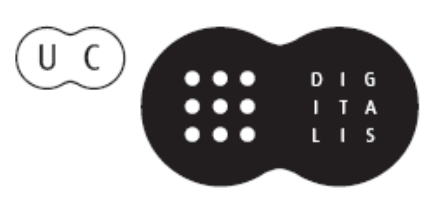




\section{Legado clássico no Renascimento e sua receção: contributos para a renovação do espaço cultural europeu}

Nair de Nazaré Castro Soares, Cláudia Teixeira (Coords.)

IMPRENSA DA UNIVERSIDADE DE COIMBRA 


\title{
O sentido universal do humano em Teixeira de Pascoaes (The universal sense of humanity in Teixeira de Pascoaes)
}

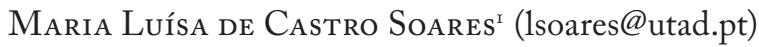 \\ Universidade de Trás-os-Montes e Alto Douro, \\ Centro de Estudos Clássicos e Humanísticos da Universidade de Coimbra
}

Resumo - O presente estudo sobre o pensamento e a obra de Teixeira de Pascoaes desenvolve-se fundamentalmente em torno de duas linhas temáticas, o messianismo nacional, ligado ao sentir lusíada, e o messianismo universal que transcende esse condicionamento para se configurar como utopia universalista ou o lugar ideal de perfeição e felicidade para o Homem unificado, à escala global, pelo Amor.

Palavras-chave - Teixeira de Pascoaes; utopia universalista; messianismo nacional; messianismo universal; união pelo Amor.

Aвstract - The present study goal was to explore the Teixeira de Pascoaes thought and work. His thought and work was developed through two main thematic lines, which were the national messianism and the universal messianism. The national messianism is linked to the feelings of being lusiad and the universal messianism transcends this conditioning to be configured as a universal utopia or as an ideal place of perfection and happiness for the unified Man, in a worldwide scale, through Love.

Keywords - Teixeira Pascoaes; utopia universalist; National messianism; Universal messianism; union through Love.

Em contexto de crise e de decadência nacional, a partir de 1910, com a revista A Águia - arauto da Renascença Portuguesa - é notória a vontade decidida de regenerar Portugal $^{2}$ e gera-se uma verdadeira doutrina da portugalidade. Ao lado de propostas concretas e da pretensa imparcialidade crítica em relação ao poder ${ }^{3}$, a revista - na sua 1. ${ }^{a}$ Série (1910-1912) e depois sob a direção de Teixeira de Pascoaes (1912-1917) - caracteriza-se globalmente pela existência de um projeto renovador dentro de uma linha idealista contrária ao modelo do positivismo dominante. Tal

${ }^{1}$ Doutora em Literatura Portuguesa pela Universidade de Trás-os-Montes e Alto Douro (UTAD). Membro do CECH-UC (Centro de Estudos Clássicos e Humanísticos da Universidade de Coimbra) e da Sociedade Portuguesa de Retórica.

${ }^{2} \mathrm{O}$ desejo decidido de regeneração do país começa a desenhar-se desde a revolução liberal de 1820 (Soares 2007a , 13-36).

${ }^{3}$ No que respeita ao objetivo renovador e regenerador de A Águia, este mantém-se ao longo das suas três séries, como se mantém o incitamento aos portugueses para que sejam fiéis à República e à Pátria. Porém, este órgão porta-voz da Renascença Portuguesa que se pretendia inicialmente imparcial, assume, na sua fase final, um comprometimento com o poder, não podendo deixar de ser, a seu modo, um órgão político, atuando no sentido de procurar soluções para a crise nacional. 
projeto fundamenta-se no nacionalismo, ou melhor, no patriotismo e alicerça-se na consciência da necessidade de uma elite, com base no conceito de Homem Superior, de origem evolucionista que Teixeira de Pascoaes atribui a Tolstoi ${ }^{4}$. Além

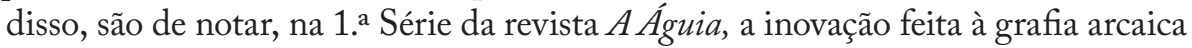
e dois itens que serão desenvolvidos na série posterior. Referimo-nos à problematização de temas científicos, mas sobretudo à intervenção da corrente saudosista, sendo os "elementos que formam a saudade: espírito e matéria", elementos de uma dialética capazes de facultarem tratamento ao pedagogo e ao visionário que simultaneamente Pascoaes soube ser.

O poeta de Marânus define e insere, na verdade, o saudosismo no largo movimento messiânico da nação que, em momento de decadência material (de queda e Inferno, na sua conceção antropológica expressa em Regresso ao Paraíso), há de abrir-se e abrir o mundo a esse "Éden" espiritual e transcendente do futuro:

"Renascer é dar a um antigo corpo uma nova alma fraterna, em harmonia com ele. O Passado é indestrutível; é o abismo, a treva onde o homem mergulha as raízes do seu ser, para dar a nova luz do futuro, a sua flor espiritual.

(...) mas a alma portuguesa existe, vem desde a origem da Nacionalidade; de mais longe ainda, da confusão dos povos heterogéneos que, em tempos remotos, disputaram a posse da Ibéria. (...) E nesse momento, mais divino que humano, a alma portuguesa gerou nas suas entranhas penetradas por uma luz celeste, a Saudade, a nebulosa do futuro Canto imortal, o Verbo do novo mundo português (...). A Saudade é o próprio sangue espiritual da Raça; o seu estigma divino, o seu perfil eterno. Claro que é a saudade no seu sentido profundo, verdadeiro, essencial, isto é, o sentimento-ideia, a emoção reflectida, onde tudo o que existe, corpo e alma, dor e alegria, amor e desejo, terra e céu, atinge a sua Unidade divina" ${ }^{\text {. }}$

O sentido religioso e saudosista que Teixeira de Pascoaes atribui à história de Portugal é incentivo à esperança. Portugal configura-se para o Poeta como o povo eleito da Saudade elevada à categoria de transcendência. Nela se centra toda a esperança mnésico-redentora7. Por ela e com ela - que é "alma da raça" -, irá afirmar-se a primazia espiritual do génio português e a nação impor-se-á moralmente ao mundo. Será então a concretização da profecia pascoalina da Era Lusiada, um império do Espírito e da Cultura", sendo que "a dimensão

${ }^{4}$ Spinelli 1981: 47.

${ }^{5}$ Pascoaes, O Esp. Lus.1912: 12, in Gomes 1988: 43.

${ }^{6}$ Pascoaes 1912: 1-2.

${ }^{7}$ Soares 2007: 418.

${ }^{8}$ Pascoaes 1990: 135.

9 Soares 2007: 351. Perfila idêntica opinião Fernando Pessoa e, mais próximo de nós, Agostinho da Silva. Todos se inspiram na divisão da história proposta pelo monge cisterciense Joaquim da Fiore (1130-1202), figura emblemática de um movimento de carácter apocalíptico- 
geográfica da viagem no Século de Ouro se projeta transfigurada na realização final da Aventura que o Império Espiritual representa" ${ }^{10}$.

No dizer de Pascoaes, os Portugueses são "este messiânico Povo que, tendo dado à Humanidade o mundo físico, compete-lhe dar agora o novo mundo moral"11.

Nos diferentes momentos do percurso espiritual e literário de Teixeira de Pascoaes, a Saudade é uma obsessão temática e uma constante na definição da antropologia essencial e peculiar do homem português, como pode verificar-se no seguinte passo da sua conferência proferida em 1912, O Espirito Lusitano ou o Saudosismo:

"Há ainda nos Portugueses um sentimento que é só deles e que só poderia ser originado pela combinação harmónica do sangue dos dois antigos ramos étnicos ${ }^{12}(. .$.$) Refiro-me à Saudade { }^{13}$."

Após a definição de Saudade, considerada a "suprema síntese espiritual" do povo português, Teixeira de Pascoaes defende e reitera a ideia de que o sentimento é algo entranho ao homem luso, incluindo, contudo, a possibilidade de uma identificação projetiva ou uma identidade cultural comum com o povo galego:

"A alma lusitana concentrou-se numa só palavra, e nela existe e vive, como na pequena gota de orvalho a imagem do sol imenso.

Sim: a palavra Saudade é intraduzível. O único povo que sente a Saudade é o povo português, incluindo talvez o galego, porque a Galiza é um bocado de Portugal sob as patas do leão de Castela" ${ }^{14}$.

milenarista que, no seu Livro da Concórdia entre o Novo e o Antigo Testamento se refere a três impérios ou idades do mundo: a Era do Pai (Antigo Testamento), a Era do Filho (Novo Testamento) e a Era do Espírito Santo ou Divino Paráclito, um tempo de fraternidade Universal. Cf. Soares 2007,47-49. O culto do Espírito Santo - propugnado em Portugal pela Rainha Santa Isabel e condenado pela Inquisição em Portugal continental por heresia - permaneceu e permanece com vigor nas ilhas Açorianas, mantendo o ideal de solidariedade e fraternidade.

${ }^{10}$ Soares 2007: 320.

${ }^{11}$ Pascoaes, O génio port., in Gomes 1988: 94.

${ }^{12}$ Estes dois ramos étnicos a que o poeta se refere são o semita, composto por fenícios, cartagineses, judeus e árabes e o ária composto por gregos, romanos, celtas, godos, normandos, etc. Segundo o nosso autor, "o ária criou a civilização grega, o culto da Forma, a Harmonia plástica, o Paganismo: o semita criou a civilização judaica, o Velho Testamento, o culto do Espírito, a Unidade divina, o Cristianismo que é a suprema afirmação da vida espiritual”. Na opinião de Pascoaes, a mistura "d'aquelas duas raças (...) em partes iguais, (...) deram origem à raça Lusitana que é, desta forma, a mais perfeita síntese de dois antigos ramos étnicos”, Pascoaes, O esp. Lus., in Gomes 1988: 49.

${ }^{13}$ Id.: 50.

${ }^{14}$ Id.: 54. 
No dizer de Maria Luísa de Castro Soares, em outro contexto, subjaz ao pensamento de Teixeira de Pascoaes o nacionalismo cultural ou o intento de regenerar a alma lusiada pelo desvelamento da sua ontologia particular. Por meio do "congeminar dialético mnésico-prospetivo e refontalizante-projetivo da Saudade, Pascoaes faz apologia de uma raça e de uma cultura portuguesas" ${ }^{15}$.

O respeito pela memória cultural do passado e pela terra (Sehnsucht $)$ - em que se configura a identidade, a História e o génio, ou espírito do povo (Volksgeist) - definem a saudade lusíada. E só no reconhecimento desta realidade ôntica será possível ao homem português a abertura ao Outro e ao futuro como horizonte de esperança:

"Fora do seu carácter, o nosso Povo nada fará de belo e duradouro. Ai dos povos que negam a sua alma e a sua tradição, e as desprezam e não querem procurar nelas as novas energias criadoras! São povos condenados irremediavelmente à morte"16

A relação com a alteridade pressupõe o reconhecimento da identidade e Pascoaes tem consciência disso, ao afirmar a necessidade de desocultação da "verdade portuguesa"17, em Arte de Ser Português. O seu pensamento perpassado pelo misticismo, pela intuição poética e pela loucura visionária não faz dele um desenraizado, mas um espiritualista lusitanizante. A demanda constante de redenção - como progressiva libertação do mal e de todo o domínio da matéria, em busca da vida do espírito -, que se anuncia na obra Regresso ao Paraíso, não é a negação da atividade material. O próprio espírito a possui, por forma a realizar no tempo um reino superior e ideal. É esse o espaço que figura no Paraíso reencontrado pelo novo Adão, o Homem em afirmação de si, produto de "uma palingénese humana de fundo" ${ }^{18}$. Ou então, é um paraíso como o que se anuncia na obra $O$ Sentido da Vida, em que o futuro a construir é uma utopia a realizar, onde "não há guerras, leis, estados, fomes, injustiças, ódios, misérias"19.

Eis forjada - em Regresso ao Paraíso e O sentido da Vida - a ideia pascoalina de universo sem fronteiras pela voz do poeta-profeta que exprime a verdade transpondo conjunturas, mas com aquela temporalidade inerente à profecia, já que o seu verbo é mensagem e ação, que resulta de um empenhamento no presente ${ }^{20}$.

${ }^{15}$ Soares 2007: 234.

${ }^{16}$ Pascoaes, "Ainda o Saudosismo...” 1912: 187, in Gomes 1988: 65.

${ }^{17}$ Pascoaes, Arte de Ser Português, 1993: 6 e 124. A “verdade portuguesa” surge mencionada no início e no final da obra didática de Pascoaes como o propósito/ objetivo e o cumprimento dela, respetivamente.

${ }^{18}$ Soares 2007: 260.

${ }^{19}$ Pascoaes, in Garcia, 1976: 293. Numa linha de continuidade ideológica, um tal ideário é perfilhado na atualidade por Agostinho da Silva.

${ }^{20}$ Porque se trata de uma utopia a realizar no tempo (no futuro e no concreto), trata-se de 
Inerente à ontologia idealista pascoalina e ao "seu" Saudosismo, ao lado da referência ao passado, há uma dimensão futurante. Mais do que um sentimento, a saudade é representação criadora de vontade. $\mathrm{O}$ apropriar-se da tradição não significa, assim, fixação ou retrocesso no tempo, mas recuperação pela memória tornada consciência no presente, da qual há de brotar um rumo de ação no futuro. O passado vale enquanto energia criadora da futuridade, como o demonstra a Homenagem a António Nobre:

"A tradição e a revolução, o passado e o futuro em amorosa concordância, eis o nosso ideal" 21 .

O verdadeiro sentido da história de Portugal, para Pascoaes, assenta na Saudade, a qual não se confunde com o passadismo, de que se defende nas páginas de $A A_{g}$ uia $^{22}$. Na linha de Duarte Nunes de Leão (1530-1608), para quem a saudade é a lembrança de uma coisa com o desejo dela, para Pascoaes, o sentimento-ideia contém estruturalmente, em consciência presente, a lembrança do passado que anima o desejo criador do futuro. $\mathrm{Na}$ fidelidade ao passado se alimenta o porvir e a Saudade é, em suma, "a sagrada lembrança do Futuro"23.

Esta conceção religiosa da Saudade, alento e esperança de um povo - que se adequa perfeitamente ao contexto global da obra pascoalina e à ambiência de crise nacional que se vivia - é fator propício ao messianismo, que se anuncia com as Trovas do Bandarra, se evidencia no providencialismo histórico de feição político-religiosa ${ }^{24}$ de Seiscentos e se transfigura, com Pascoaes, numa ideia de marcha para o progresso da Humanidade até à plenitude perfeita da consciência.

$\mathrm{Na}$ linha de Hegel e, entre nós, na linha de Oliveira Martins e Antero de Quental, o providencialismo pascoalino pretende mostrar que o mundo marcha num sentido ascensional e dialético, na medida em que toda a História se explica como evolução de progresso da Humanidade, sendo que os acontecimentos se relacionam entre si num sistema triádico de tese, antítese, síntese.

Em Regresso ao Paraíso, há notórios marcos desse processo evolutivo expresso nos três momentos em que se estrutura internamente o discurso.

utopia com profecia.

${ }^{21}$ Pascoaes 1991: 69.

${ }^{22}$ Em polémica aberta nas páginas de A Águia e em resposta António Sérgio na "Epístolas aos saudosistas" (Sérgio 1913: 97-99), que põe em causa a atitude progressista do Saudosismo, Teixeira de Pascoaes afirma, no artigo "Mais Palavras ao Homem da Espada de Pau", o seguinte: "Tornarei a repetir que o Saudosismo tem por alma a Saudade... a lembrança e o desejo, ouça bem! Se um dos seus elementos é espiritual e contemplativo, o outro é material e ativo. Se um é alma que sonha, o outro é corpo que trabalha”. Cf. Pascoaes 1914: 1.

${ }^{23}$ Pascoaes 1986: 112.

${ }^{24} \mathrm{O}$ providencialismo da história de Portugal evidencia-se já no período de Quinhentos, designadamente, n'Os Lusiadas (Cf. Soares 2004, 433-459). Ganha, contudo, evidência nos autores do período de Seiscentos que seguem e aprofundam, neste campo, o ideário camoniano. 
Adão e Eva no Paraíso é a tese (quase só evocada no discurso como tempo de lembrança ou reminiscência). Adão e Eva depois da queda no Inferno é a antítese. Adão e Eva no novo Paraíso é a síntese. Este novo Paraíso - que conglomera o primeiro, num outro estado de humanidade - não é já o paraíso da inconsciência, mas o da Primavera espiritual do Homem:

"Olhai o novo Adão no Paraíso

Entre rosas, os lírios e os perfumes

Da sua Primavera espiritual”25

O sentido profético de abertura à consciência e à lucidez que Pascoaes atribui ao homem universal também emerge no homem luso e aplica-se ao caso português. A esse processo dialético de ascese até à plenitude perfeita dá expressão - no contexto cultural português - a poesia de saudosistas, que Pascoaes considera um "sinal dos tempos", o "acordar idealista e místico do génio da Raça" ${ }^{26}$. Como emissário dessa Era Lusíada ou império da cultura, Pascoaes, pela Saudade, abrirá caminho a uma nova descoberta portuguesa ${ }^{27}$ como experiência do mundo. No dizer de Maria Luísa de Castro Soares,

"não se trata já da atenção dada ao mundo exterior, baseado nos limites dos sentidos e da razão, como aconteceu nos alvores do novo ciclo histórico e antropológico da Idade Moderna, o período do Renascimento e os Descobrimentos. É a outra face interior do mundo, que se ausculta nas obras de imaginação e de mística, onde as descobertas em extensão dão lugar àquelas em profundidade: as do espírito" 28 .

Nesse espaço de imaginação, de sonho, ou de Saudade caminham de par a revelação de um futuro glorioso para Portugal e a demanda de transcendente, que é também esperança no "novo Adão" ${ }^{29}$, símbolo do Homem à escala universal. Esse Homem englobante e total, como se define em Regresso ao Paraíso, encontra o verdadeiro ser e um sentido para a vida e para o mundo, depois da superação de dicotomias:

"Que são o Bem e o Mal? O meu Passado.

Mas eu vejo outra aurora que se eleva acima do horizonte..." ${ }^{30}$

\footnotetext{
${ }^{25}$ Pascoaes 1986: 167.

${ }^{26}$ Pascoaes, A Era Lus., in Gomes 1988:161.

${ }^{27}$ Costa 1980: 32.

${ }^{28}$ Soares 2007: 237.

${ }^{29}$ Pascoaes 1986: 167.

${ }^{30}$ Pascoaes 1986: 143.
} 
Refazendo e recriando a "vida" e a "história" no Novo Paraíso, Adão virá dizer "sim" à terra como absoluto;

“...à Terra da Promessa

à porta, aberta já, do Paraíso" ${ }^{11}$

Nessa terra ou novo paraíso sem o "velho Deus", os homens reunificam-se no Homem, porque o "novo Deus" é o que a sua vida constrói. Com base num "acentuado idealismo monista" ${ }_{32}$, o disperso dá lugar ao Uno, ao Homem substancial do qual os demais seres humanos são modos ou manifestações.

Regresso ao Paraíso é, então, a procura eterna de uma Terra Prometida e uma aventura espiritual que se desvela, enquanto Adão - personagem mítica -, "pelo veículo da Saudade, viaja entre dois mundos: do Inferno ao Paraíso" ${ }^{33}$.

Com manifesta influência platónica, a viagem de Adão não é meramente a busca do Éden, mas busca de encontro do Si-mesmo. Eis a razão pela qual ao longo dessa busca Adão sofre alterações cambiantes de estado e claramente mudança de objetivos, já que o sujeito da procura se torna no objeto procurado. $\mathrm{O}$ homem inicia assim o seu processo ascensional e reorganiza-se no novo Homem, sendo que o espaço ideal é a aurea aetas, o arquetípico lugar de felicidade, ou a conquista da Terra Prometida, na linguagem messiânica:

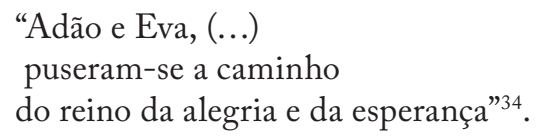

Esse reino proposto na alegoria pascoalina - assumindo uma secularização da linguagem messiânica - é ucrónico, utópico ${ }^{35}$, produto da imaginação e funciona como chave para aclarar a ideia de reunificação de identidades na Unidade. E o processo é um progresso, um percurso iniciático ascensional, um evolucionismo espiritual do homem da feritas para a bumanitas que culmina na divinitas, como o refere Pascoaes em O Bailado:

"Em toda a minha obra, compreendi o homem como sendo a expressão das coisas conscientes, elevada a uma altura já divina" 36 .

${ }^{31}$ Id.: 167.

${ }^{32}$ Garcia 1976: 238.

${ }^{33}$ Soares 2007: 261.

${ }^{34}$ Pascoaes 1986: 165.

${ }^{35} \mathrm{Na}$ cultura ocidental e, de modo específico na literatura, uma das projeções mais marcantes da Terra de Promissão messiânica é a forma secularizada que assume nas chamadas utopias, surgidas a partir do Renascimento, segundo o modelo e a cunhagem de Thomas More (1478-1535).

${ }^{36}$ Pascoaes 1987a: 16 
A divinização, contudo, não transcende o próprio Homem sobre-humanizado que é, para o ateoteísta ${ }^{37}$, a realidade última: "O homem é a única realidade" 38 .

Num tempo europeu marcado pelo contexto do primeiro conflito mundial, Pascoaes aspira e sustenta, na sua obra de feição universalista Regresso ao Paraíso, a "maior idade" das "almas sem brancas e sem rugas, capazes de crer e querer" ${ }^{39}$, a Infância consciente ou a "primavera espiritual"40 do futuro que só a reminiscência permite recriar. Nessa "maior idade", semelhante "à idade primeira" transfigurada, reside, segundo Pascoaes, "a nossa melhor esperança no pátrio ressurgimento" imaginar (...), de criar para além das aparências vulgares e imediatas..." ${ }^{\prime 2}$, às almas que "possuem o poder visionário, o estranho poder que transfigura a velha fisionomia das coisas" ${ }^{43}$, a elas o poeta endereça a sua "palavra obscura... em cuja obscuridade cintila remota estrela" ${ }^{{ }_{4}}$.

A estrela que o poeta acende é a Saudade, orientadora do pensamento pascoalino e que, segundo o vate, será capaz de iluminar o "génio lusíada", encaminhando-o ao "encontro do espírito humano, ansioso e pálido no seu cárcere" ${ }^{\prime 45}$. E o poeta interroga-se:

"Porque não? Se ele (o génio lusíada) contém, em si, na sua essência de Saudade, um reflexo divino imprescindível às mais íntimas aspirações da Criatura!"46

Como doutrinador empenhado da Saudade, Pascoaes vê nela o seu modelo de referência, a protagonista da sua missão poética e patriótica, e a única força propulsora capaz de dar "aos portugueses a consciência da sua personalidade lusitana e humana"47, isto é, capaz de os tornar "solidários com a pátria e o resto do mundo" ${ }^{48}$.

Pascoaes, na verdade, não isola Portugal das restantes nações, mas menospreza, no seu país como na Europa, toda a civilização fundamentada numa cultura positiva e secularizada, desprovida de sentido religioso, apenas visando o progresso, essa

${ }^{37}$ Soares 2010: 612. O ateoteísmo (palavra forjada por Pascoaes, que é resumo e metatexto da espiritualidade pascoalina), no dizer de João Mendes, é uma tentativa do Poeta se reconciliar com a ciência (Mendes 1979: 97).

${ }^{38}$ Pascoaes 1914: 164.

${ }^{39}$ Pascoaes 1914 A Era Lus., in Gomes 1988: 156.

${ }^{40}$ Pascoaes 1986: 83.

${ }^{41}$ Pascoaes 1914 A Era Lus. ("Prefácio"), in Gomes, loc. cit.: 156.

${ }^{42}$ Ibid.

${ }^{43}$ Ibid.

${ }^{44}$ Ibid.

${ }^{45}$ Id.: 160 .

${ }^{46}$ Ibid.

${ }^{47}$ Id.:161.

${ }^{48}$ Ibid. 
"divindade egoísta e feroz rodeada de intolerantes e rubros sectários - corações encarvoados que perderam o divino sentido das Coisas; almas cegas de fumo tentando reduzir o Universo às trevas em que vivem ou, melhor, em que se deslocam..." ${ }^{49}$

O poeta ainda compreende que os "povos incaracterísticos, mais apagados que os rebanhos dos seus outeiros" ${ }^{50}$, interpretem a realidade como se o Espírito não existisse. Daí que

“adorem o progresso, o esplendor do ouro, os silvos das locomotivas, velocidades de automóveis, voos de aeroplanos, enfim, a forma burguesa da Civilização" ${ }^{51}$.

É, porém, ilusão a "obsessão científico-industrial” que faz prevalecer uma ética individualista e utilitária. É diminuído o homem de qualquer continente do globo que, ao favorecer a máquina (na rejeição do espírito), se torna menos homem:

"Oh, que ilusão, que estúpida ilusão a do homem que tenta matar a divina fome de espírito, dando-lhe a roer carvão e ferro! Ele confunde o movimento simples com a vida complexa, o que se desloca no espaço com o que sonha no Infinito" ${ }^{52}$.

No seio da crise que permeia o mundo moderno, Pascoaes, assumindose profeta da Saudade, vem chamar a atenção para a renascença, no homem português, do sentido "religioso, latente no génio" ${ }_{53} \mathrm{da}$ raça. Como poeta e vate atento, vem apelar ainda para o que considera a essência, a alma portuguesa, capaz de uma benéfica renovação do país e da humanidade, capaz de criar um "Portugal português e, ao mesmo tempo, humano" ${ }^{54}$.

A Saudade - particular, exemplar e elevada à categoria de símbolo, em Pascoaes - ajuda o homem a ser português e a aceder ao universal. Neste contexto, o "sentimento-ideia" ${ }_{55}$ surge simultaneamente como placenta e objetivo da alma lusiada e oferece a esta alma a solução para as dificuldades da sua própria definição ou identidade. O poeta assevera mesmo que "a alma lusíada esconde, no seu íntimo, uma nova luz de Verdade e Beleza, um novo sonho evangélico" ${ }_{56}$. Neste sentido, a Saudade desempenha também o papel de uma religião, porque

\footnotetext{
${ }^{49}$ Id.:159.

${ }^{50}$ Ibid.

${ }^{51}$ Ibid.

${ }^{52}$ Id.: 158 .

${ }^{53}$ Id.:160.

${ }^{54}$ Id.:159.

${ }_{55}$ Pascoaes A Águia 1912: 2.

${ }^{56}$ Pascoaes 1914 A Era Lus. , in Gomes, loc. cit.: 159.
} 
assegura integridade a "um Povo desvirtuado na sua essência, anemizado na sua íntima força criadora, enfim, da alma, que é o pior dos males" ${ }^{57}$.

A Saudade torna-se, então, criadora de valores para os portugueses, convertidos por ela e nela em modelo e exemplo para o Outro.

De acordo com o ponto de vista pascoalino, pode dizer-se que a desvirtuação da identidade "que lavra, sobretudo, nas cidades (...), sob a influência dum ensino estéril e duma vida noturna de café" ${ }_{58}$, equivale a uma nova queda. O homem português teria perdido a capacidade de reconhecer o seu génio e, portanto, de o compreender e assumir, vivendo uma vida que "adultera a sensibilidade própria, a herança étnica no aspeto mais transcendente" ${ }_{59}$, que "embrandece e dilui" o "carácter, o mármore em que esculpe a criatura" ${ }^{60}$. Neste contexto, o apelo do poeta não deixa de fazer-se, consciente de que o homem (Adão, no poema alegórico Regresso ao Paraíso) caído ao nível da consciência dilacerada em pleno inferno tinha conservado - pela reminiscência - "a Saudade ideal do Paraíso" ${ }^{61}$.

De igual modo, "uma certa casta de portugueses descontentes com a sua raça, ou por falta de poder compreensivo e representativo"'62 é sintoma de queda do espírito identitário. E essa "casta desnacionalizadora" aparece sempre "com os primeiros sintomas da nossa decadência" ${ }^{3}$. Porém, mais profunda que essa queda - provocada por uma "casta daninha", mas não espiritualmente cega ${ }^{64}$ - é a degeneração da "gente nova" citadina, "cuja inteligência perde o viço, a graça, o poder original que concebe e cria de per si” ${ }^{65}$. É uma espécie constituída de seres sem sombra ${ }^{66}$, sem essência, onde se não reflete o divino. Esta reflexão pascoalina é feita não sem acusar a descaracterização que afeta Portugal, mas também a Europa, que lhe serve de modelo, onde

"Em vez de seres vivos definindo a sua sombra inconfundível, aparecem (...) formaturas humanas, indecisas, sem pátria, sem passado, e, portanto, sem

\footnotetext{
${ }^{57}$ Id.:163.

${ }^{58}$ Ibid.

${ }^{59}$ Ibid.

${ }^{60}$ Ibid.

${ }^{61}$ Pascoaes 1986: 54.

${ }^{62}$ Pascoaes 1914 A Era Lus., in Gomes 1988: 162.

${ }^{63}$ Id.: 163.

${ }^{64}$ Id.: 162 .

${ }^{65}$ Id.: 163 .
}

${ }^{66}$ A sombra, em Pascoaes, não tem a conotação platónica da aparência, do fenómeno. Ao invés, a sombra vale mais do que a realidade que projeta: é o númeno. A obra Marânus encerra com o capítulo "A Saudade e a Sombra de Marânus", onde o poeta defende a consubstanciação da Saudade na alma do homem luso. Este, desmaterializado, tornado "sombra", é elevado à categoria da sua própria essência, logo, a sombra encerra uma dimensão ôntica. Cf. Soares 2007: 372 . 
futuro. São fantasmas, cheios de tédio e cepticismo, infestando a política, a imprensa, a literatura" ${ }^{67}$.

Pascoaes dá ao sentido da existência humana e ao da existência pátria uma interpretação espiritualista. A decadência é condição do progresso, como o trágico da vida é subjacente ao valor moral e edificante. Na condição mortal do indivíduo (homem ou Pátria), está o gérmen do seu renascer: a queda pressupõe a redenção, das pátrias e dos homens.

Dir-se-ia que à luz vivificante da Saudade, Pascoaes ergue uma ontologia do ser e do ser português, a quem reserva um final que corresponde à instauração do reino messiânico. Através da Saudade reclama a identidade da raça e visiona um novo ciclo antropológico, uma futura civilização ideal. Um tal quadro final, a um tempo aventura e perplexidade sobre o futuro, pressupõe meios. Daí que conteste - para a situação concreta de Portugal - o " princípio materialista, egoísta, intolerante, de importação"68. E fá-lo de modo programático e declarado em Arte de Ser Português. Na verdade, para Pascoaes, é no reconhecimento da identidade (verificação das qualidades e crítica aos "defeitos da alma pátria”) que se chega à universalidade. Ser Português, como ser Europeu, é ter uma identidade própria e distinta e, simultaneamente, é ser universal. $O$ desejo do poeta com o seu programa é o de alcançar a máxima perfeição do espírito bumano dos povos, dentro do seu carácter.

O universal e o particular só em relação entre si têm sentido e existência. Assim, no entender de Pascoaes, é essencial o ensino da

"verdade portuguesa, cujo conhecimento se impõe como força reconstrutiva da Pátria, dentro do seu carácter, da sua alma tradicional evoluída até ao grau de perfeição atingido pelo espírito humano, no século presente" 69 .

A reconstrução e a esperança profética de ressurgimento nacional, a partir de uma situação de crise ou traumatismo históricos: eis o idealismo patriótico que, de modo diverso mas confluente, a pedagogia e o visionarismo pascoalinos encerram. Se o visionarismo saudosista de Pascoaes se inclina a ser o exaltador da poesia e do povo português, "o mais belo representante do espírito humano"70, o seu pensamento pedagógico, em Arte de Ser Português, visa igualmente ordenar, desenvolver e aperfeiçoar, isto é, "instruir, educar, criar portugueses" ${ }^{71}$ para o

\footnotetext{
${ }^{67}$ Pascoaes 1914 A Era Lus., in Gomes 1988: 164.

${ }^{68}$ Id.,161.

${ }^{69}$ Pascoaes 1993: 6.

${ }^{70}$ Pascoaes 1913 O génio port., In Gomes 1988: 83.

${ }^{71}$ Pascoaes 1993: 6.
} 
ideal messiânico ${ }^{72}$. Só assim, pela educação portuguesa,

“o antigo sonho da Raça caminhará de perfeição em perfeição até conquistar, um dia, a sua forma de atividade, cristalina, contagiosa, que deslumbra e revoluciona as almas, casando-as para uma nova existência espiritual, religiosa, florescida de eternas esperanças". ${ }^{73}$

Pascoaes, numa linha pedagógica, visionária, edificante e iniciática, manifesta o intuito de portugalizar os portugueses, essencialmente, através de alguns artigos d'A Águia (1912-1914); em conferências como O espírito lusitano ou o saudosismo (1912); O génio português na sua expressão filosófica, poética e religiosa (1913); A era lusíada (duas conferências) (1914); e em obras como Os poetas lusíadas (1918) e Arte de ser português (1915).

A última das obras citadas - que pouco traz de novo à mensagem saudosista - é, porém, aquela que melhor explicita a sua mensagem pedagógica. Já como mentor espiritual do Saudosismo, Pascoaes "ensina" através dela a verdade, formulando-a de modo deliberado e sistemático. Ao poder da palavra poética sobrepõe-se, em Arte de ser português, o prestígio ascendente do ver e do esquematizar, o espírito "científico", classificador e simplificador.

Nesta obra, escrita "em quinze dias" ${ }^{74}$, com a finalidade de ser adotada como um manual de ensino nos liceus, as frases sentenciosas são sujeitas a um breve desenvolvimento e explicação, próprios de um manual escolar. No prefácio à obra, feito pelo próprio autor, Pascoaes revela o seu propósito:

"Este livro, não pelo seu valor literário, mas pelas verdades que encerra, deveria ser lido, estudado e comentado nos cursos de Literatura e História Pátria, sendo certo que poderia mesmo constituir um curso independente e último dos liceus, pois a sua matéria abrange, numa síntese superior, as matérias tratadas em quase todos os cursos liceais" 75 .

Caracteriza esta obra - onde o poeta se pretende mais o pedagogo do que o visionário - o facto de tocar variadíssimos temas que se poderão resumir a um determinismo cultural com base na raça, no meio, enfim, no nacionalismo peculiar à filosofia da Saudade. Na verdade, enquadrando o homem na paisagem, o poeta crê adivinhar os traços de uma alma e de um mundo genuinamente lusiadas. Enquanto texto, Arte de ser português ficaria na perenidade, segundo o seu autor, "não pelo seu valor literário", mas pela sua eficiência orientadora progressiva. De facto, para Pascoaes, só o ensino da verdade portuguesa pode

\footnotetext{
72 Patrício 1996: 114.

${ }^{73}$ Pascoaes, 1914 A Era Lus., in Gomes 1988: 160.

${ }^{74}$ Pascoaes 1993: 9.

${ }^{75}$ Id.: 5 .
} 
salvar e reconduzir Portugal ao caminho "de um novo sonho (...) humano"76. A obra seria assim de ensino e propaganda de uma "verdade" com que se pode levantar o moral da nação, abatido pelo complexo de inferioridade em que Portugal havia historicamente caído. O sentido da existência de Portugal pela desocultação do "ser português", pela interpretação da sua história, pela acentuação de sentimentos caraterísticos da personalidade portuguesa ${ }^{77}$ - desde o "génio de aventura" 78 , ao "espírito messiânico" 79 , à "vil tristeza" ${ }^{80}$, de evocação camoniana são alguns aspetos que se devem considerar, segundo Pascoaes, nessa verdadeira didática da portugalidade.

Sublinha-se, em relação à obra de Teixeira de Pascoaes, o sentimento patriótico, evitando chamar-se-lhe nacionalismo, porque se entende que a idolatria da nação erigida como valor supremo - que aconteceu em política - é tendencialmente xenófoba e distinta, pelos meios e pelos objetivos, da literatura saudosista sempre contrária à ilusória segurança da lógica e da convenção. Neste sentido, a escrita do Poeta dignificadora da alma pátria opera-se na e pela liberdade intelectual, ao invés da moldagem de mentes com rejeição sistemática da alteridade. Isso seria, com evidência, um sinal de tendenciosidade indicadora de uma pouquidão de pensamento, onde não cabe o poietês da portugalidade, que foi indubitavelmente um espiritualista lusitanizante consciente da ação pela poesia, mas não um xenófobo. Na verdade,

"O poietês é o que faz, cria, constrói a pátria, preocupando-se, como vate, com a situação do ser português, exilado em si. É neste contexto que se deve encarar a obra de intuitos pedagógicos, onde é inegável o sentimento patriótico e onde as ideias de raça, de pátria, de verdade portuguesa não são na sua essência xenófobas, antes favorecem a comunhão humana" ${ }^{\text {81 }}$.

O patriotismo pascoalino é, assim, um sentimento que se dirige, pelo verbo, ao grupo nacional de que o poeta faz parte; é a tendência que o leva a interessar-se pelo destino do seu país, procurando a sintonia dos homens que nele habitam; é a voz impregnada de espiritualidade e participante na vida da Pátria com a qual o poeta partilha alegrias, sofrimentos e para quem adivinha esperanças futuras. Todavia, nacional e universal não são conceitos opostos para Pascoaes. Sem paradoxo, pode afirmar-se que o seu nacionalismo possui uma dimensão universalizante, porque nele se prevê a reunião dos homens no

\footnotetext{
${ }^{76}$ Id.: 108-109.

77 Pascoaes consagra dois capítulos de Arte de ser português à enumeração dos defeitos e qualidades da alma pátria (respetivamente, nas páginas 95-104 e 87-93).

${ }_{78}^{78}$ Pascoaes 1993: 89-90.

${ }^{79}$ Id.: $90-92$.

${ }^{80}$ Id.: 100 .

${ }^{81}$ Soares 2007: 296.
} 
Homem. A memória rácica, vestigial, o inconsciente coletivo deve existir em todas as nações, o que não exclui - antes faz prever - o arquétipo do homem ou padrão de estruturas composto pelas experiências básicas universais, como o documentam as palavras de Leonardo Coimbra, no prefácio que fez à segunda edição de Regresso ao Paraíso de Teixeira de Pascoaes, onde defende que "o homem é um ser universalista" ${ }^{22}$, e acrescenta que:

"A alma do homem tem a sua zona de contacto com a universalidade dos seres: quer a percorramos em superfície de olhos abertos sobre os mundos, quer a atravessemos em angústia e profundidade, é sempre a uma nova coincidência com o Universo que teremos de chegar" ${ }^{\prime 3}$.

Em Arte de ser português, além do ensino da "verdade portuguesa" ${ }^{44}$, existe sobretudo o propósito de aplicar ao plano da realidade concreta esse conceito ideal, para que ele dê "nova energia aos Portugueses" ${ }^{85}$. Assim, o poeta encerra a obra pretensamente didática com a comparação conclusiva: "Também o platonismo tornado sentimental e popular, originou o Cristianismo que abriu uma nova era à alma humana" ${ }^{86}$. Ora, o intuito declarado de abrir "uma nova era à alma humana" com o seu Saudosismo ultrapassa o plano educativo do homem Português, ou mesmo Europeu, e abre campo ao universal com a proposta de uma tríade de valores:

"Acreditemos nos seres espirituais, Família, Pátria, Humanidade, as três pessoas de Deus, traduzindo formas de vida superiores à nossa, e às quais, portanto, nos devemos sacrificar, amando, lutando e trabalhando. E então não mentiremos à nossa natureza escrava que quer ser livre e ao nosso destino de sacrifício e redenção" 8 .

Familia, Pátria, Humanidade, em gradação ascendente, são os três itens fundamentais da ética idealista pascoalina para o ser Português, ou - desprovido de diferenças e contingências - para o Homem Universal.

Sob muitos aspetos menos moderno do que autores de gerações anteriores ${ }^{88}$, Pascoaes cultua a Pátria e o homem português, numa linha tradicionalista, transfigurando-os pela sua visão de homem religioso. Por outro lado, como pedagogo, sabe que as nações tomam consciência de si próprias mediando as

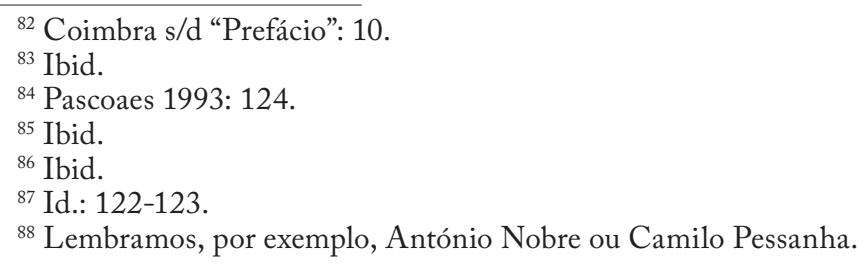


diferenças que as singularizam: marcam-se, demarcando-se; demarcam-se, marcando-se. É neste sentido que devemos entender o "nacionalismo" literário de Pascoaes: o seu amor da pátria abarca a fraternidade com as outras pátrias e a filiação à "Cidade de Deus".

A defesa do espírito nacional - essencialmente nos seus valores de ordem estética, cultural e religiosa - faz-se com vista à universalidade. A pátria modelo de "verdade portuguesa" ${ }^{99}$ é uma pátria essencial. Assim sendo, enquanto civilização ideal ou norma de vida social superior, é necessariamente supranacional.

A profecia pascoalina do homem, de feição universalista, enuncia, na verdade, a passagem do ser inautêntico ao ser autêntico. Aquele encontra-se afundado na massa, no objetivo, na nivelação do concreto: é o Mal, representado em Regresso ao Paraíso pelo Inferno.

Textualmente, em Regresso ao Paraíso, figuram no Inferno como "dolorosos Náufragos" ${ }^{90}$ os grandes vultos históricos e literários do Ocidente, desde "Virgílio", a "Dante", a "Espártaco", a "Giordano", a "Ugolino", a "Tântalo"91.

Afetado por essa queda está também o espaço sociocultural português desde o mais remoto passado, a herança e memória cultural coletiva, aos exemplos paradigmáticos de homens e mulheres que marcaram a história. Aí desfilam figuras históricomíticas, como "Viriato", "O Fantasma de Afonso" Henriques e o do "Mestre"92, "Diogo Coelho", "D. Pedro Primeiro", a "Defunta (Inês), sentada sobre um trono" ou "A Sombra de Mouzinho e a sua Audácia" Inferno também as maiores figuras da sociedade ocidental e o escol de artistas e literatos nacionais, com a sua obra, desde Bernardim, a Camões, a Camilo, a Eça, a Antero... ${ }^{94}$.

O Inferno pode ser interpretado como o tempo da queda do Ocidente, imagem da decadência cultural, não apenas portuguesa, mas ainda europeia. A Europa, na sua história política, cultural e literária encontra-se decaída, mas suscetível de santificação ou de "regresso ao paraíso". E trata-se de um regresso, porque o tempo da felicidade é identificado com o tempo da inocência, do passado paradisíaco ou com a Idade de Ouro, ainda reminiscentes no Adão decaído. O tempo de felicidade é também identificado com a saudade do futuro, a saudade profética, a "renascença do seu ser" ${ }^{55}$ que envolve Adão "desde o instante / em que seus pés na Terra se firmaram" ${ }^{96}$.

\footnotetext{
${ }^{89}$ Id.: 124.

${ }_{90}$ Pascoaes 1986: 30.

${ }^{91}$ Id.: 32.

${ }^{92}$ Ibid.

${ }^{93}$ Id.: 31.

${ }^{94}$ Id.: 32.

${ }^{95}$ Id.: 66.

${ }^{96}$ Ibid.
} 
O profetismo visionário de dimensão universalista ou a filosofia pascoalina do homem e da Criação exposta em Regresso ao Paraíso consiste no anúncio de uma redintegratio in statum pristinum. Esta renovação de um modo de ser primitivo como ideal de humanidade futura hipertrofiada nas suas forças espirituais problematiza um mundo real. É todo um tempo presente, de progresso tecnológico e de bemestar material mumificador da vida do espírito que implicitamente se critica. É este estado atual de humanidade que o poeta coloca em ambiente delirante e infernal. E embora o profeta civilizador insista numa ideia nacionalista de grandeza - o "culto da alma pátria ou da Saudade erigida em Pessoa divina" - o seu "sonho nacional de Renascença" ${ }^{88}$ culmina sempre num ideal de civilização, cujo "Espírito é o Fim"99, ou cujo fulcro é - no dizer de Leonardo Coimbra sobre Regresso ao Paraíso - "a Memória e a mnésica redenção do Universo"100.

Mesmo o percurso de Marânus ${ }^{101}$ - definido na obra homónima como o "luso peregrino da aventura" 102 - é uma caminhada para a "suprema e final revelação" ${ }^{103}$ espiritual, para uma nova era gnosiológica e humana.

Dito de outro modo, nas várias obras, sem negar os traços peculiares e diferenciadores do génio, da cultura e da espiritualidade portuguesas, Pascoaes encara a "nova civilização"104 como a realização maior, mais evoluída, da mais alta ideia de Homem, em "pleno abraço da Unidade reconquistada" ${ }^{105}$. A civilização ideal, a era do Espírito é necessariamente universal, pois prevê, como em Regresso ao Paraíso, a convergência das consciências humanas, reunidas no Amor "que aumenta a Vida, em vez de a encerrar no claustro da sua paixão separatista”"106, um Amor monista "que une sem separar"107:

"O amor, o amor sagrado, que destrói

as distâncias e o tempo, colocando

as almas sob a luz da mesma estrela." ${ }^{108}$

${ }^{97}$ Pascoaes 1993: 118.

${ }^{98}$ Id.: 119.

${ }^{99}$ Id.: 120 (nota).

${ }^{100}$ Coimbra s/d.: 17 .

${ }^{101}$ O Marão, na obra Marânus de Pascoaes, é montanha real e mítica e a nova rota de aventura do luso peregrino. Cf. Soares 2010: 221-133.

102 Pascoaes 1990: 18.

${ }^{103}$ Id.: 147.

${ }^{104}$ Pascoaes 1993: 113.

${ }^{105}$ Coimbra s/d.: 23.

106 Idem, 21.

${ }^{107}$ Ibid.

${ }^{108}$ Pascoaes 1986, 166. 


\section{REFERÊNCIAS BIBLIOGRÁFICAS}

Coimbra, Leonardo (s/d.), "Prefácio" a Regresso ao Paraíso. In Obras Completas de Teixeira de Pascoaes. Vol. V (Introdução e aparato crítico por Jacinto do Prado Coelho). Lisboa, 9-31.

Costa, Dalila Pereira da (1980), "Três ensaios sobre Marânus", Nova Renascença, vol. I, Revista Trimestral de Cultura, Associação Cultural "Nova Renascença”. Porto, 32-48.

Garcia, Mário (1976), Teixeira de Pascoaes. Contribuição para o Estudo da sua Personalidade e para a leitura Crítica da sua Obra. Braga.

Gomes, Pinharanda (1988), "Nota Proemial". In A Saudade e o SaudosismoDispersos e Opúsculos. Lisboa.

Mendes, João (1979), Literatura Portuguesa IV. Lisboa.

Pascoaes, Teixeira de (1912), "Renascença”, A Águia, II Série: 1-2.

Pascoaes, Teixeira de (1914), A Águia, II Série, no 6: 1914, 164.

Pascoaes, Teixeira de (1914), "Mais Palavras ao Homem da Espada de Pau", $A$ Águia, II Série, no31: 1.

Pascoaes, Teixeira de (1976), O sentido da vida, in Mário Garcia (apêndice), Teixeira de Pascoaes. Contribuição para o Estudo da sua Personalidade e para a leitura Crítica da sua Obra. Braga, 293-294.

Pascoaes, Teixeira de (1986), Regresso ao Paraíso. Lisboa.

Pascoaes, Teixeira de (1987), Os Poetas Lusíadas. Lisboa.

Pascoaes, Teixeira de (1987a), O Bailado. Lisboa.

Pascoaes, Teixeira de (1988), A Era Lusíada (prosa, conferência), [1ª ed. 1914], Porto, "Renascença Portuguesa", in Pinharanda Gomes (ed/coord.) A Saudade e o Saudosismo-Dispersos e Opúsculos. Lisboa, 155-173.

Pascoaes, Teixeira de (1988), "Ainda o Saudosismo e a Renascença", [1 $1^{\mathrm{a}}$ ed. 1912], A Águia, II Série, n. ${ }^{0} 12$, Dezembro 1912, 185-187, in Pinharanda Gomes (ed/coord.) A Saudade e o Saudosismo. Dispersos e Opúsculos. Lisboa, 63-65.

Pascoaes, Teixeira de (1988), O espírito lusitano ou o Saudosismo, [1ª ed. 1912], Porto, "Renascença Portuguesa", in Pinharanda Gomes (ed/coord.) $A$ Saudade e o Saudosismo: Dispersos e Opúsculos. Lisboa, 43-58.

Pascoaes, Teixeira de (1988), O génio português na sua Expressão Filosófica, Poética e Religiosa, [1 $1^{\text {a }}$ ed. 1913], Porto, "Renascença Portuguesa", in Pinharanda Gomes (ed/coord.) A saudade e o saudosismo - Dispersos e opúsculos. Lisboa, 67-95.

Pascoaes, Teixeira de (1990), Marânus. Lisboa. 
Pascoaes, Teixeira de (1991), "Homenagem a António Nobre", in Cadernos do Tâmega 6, Revista semestral de Cultura 69.

Pascoaes, Teixeira de (1993), Arte de ser Português (prosa didática) [1ª ed. 1915]. Lisboa.

Patrício, Manuel Ferreira (1996), O Messianismo de Teixeira de Pascoaes e a Educação dos Portugueses. Lisboa.

Sérgio, António (1913), "Epístolas aos saudosistas”, A Águia, IIa série, no 22, Porto: $97-99$

Soares, Maria Luísa de Castro (2004), "Providencialismo Histórico e Ideias Político-Sociais n'Lusíadas de Camões”, Humanitas 56: 433-459.

Soares, Maria Luísa de Castro (2007), Profetismo e Espiritualidade de Camões a Pascoaes, Coimbra.

Soares, Maria Luísa de Castro (2007a), Nas Encruzilhadas do Século XX. António Sardinha e Teixeira de Pascoaes. Vila Real.

Soares, Maria Luísa de Castro (2010), "Marão: rota do sagrado em Teixeira de Pascoaes", Revista de Letras, 2a Série, no 9: 221-233.

Soares, Maria Luísa de Castro (2010), "Idealismo Histórico e Espiritualidade Portuguesa em Camões e Pascoaes", in Theologica, 2. a Série, 45: 599-612.

Spinelli, Miguel (1981), A Filosofia de Leonardo Coimbra. O homem e a vida dois termos da sua antropologia filosófica. Braga. 